\title{
A ciência de Goethe: Em busca da imagem do vivente
} MAGALI MOURA ${ }^{I}$

\section{Os escritos científicos de Goethe ${ }^{1}$ \\ Que seja minha única felicidade, tocar-te, Natureza!}

A $S$ VARIADAs e numerosas atividades exercidas ao longo dos mais de oitenta anos de vida do poeta, romancista e dramaturgo, autor de Fausto, Werther e Wilhelm Meister, é fato quase desconhecido pelo público leitor brasileiro de modo geral e algo raramente destacado em ensaios que acompanham os livros editados por aqui. ${ }^{3}$

Para além de suas atividades literárias, Goethe enveredou por diversos caminhos. Ao longo de sua permanência no ducado de Weimar e Eisenach, foi designado pelo grão-duque Karl August para integrar o conselho privado da corte e, ao longo do tempo, alcançou a mais alta posição no serviço público, tornando-se ministro de Estado em 1815. Foi responsável pelo gerenciamento do trabalho em diversas comissões, o que hoje em dia corresponderia a pastas de governo, assumindo de forma intermitente a direção da comissão de reativação das minas de prata e cobre da região de Ilmenau, assim como das comissões de guerra, de estradas, de construções, de parques e jardins, de calçamento de ruas, de saneamento, de finanças, de supervisão da escola livre de desenho, bem como se tornou responsável pela contratação de professores e pela construção do jardim botânico da Universidade de Jena, ${ }^{4}$ além de, por vários anos, ser o diretor de teatro de Weimar e da biblioteca da corte. ${ }^{5}$ Como implicação direta dessas múltiplas atividades profissionais e não só burocráticas, Goethe se envolve com distintos campos do saber, angariando diversas experiências que serão determinantes para o fomento de seu interesse pelo conhecimento, além de estabelecer contato direto com pesquisadores, filósofos e cientistas das mais diversas áreas. Testemunhos dessa diversidade nos fornecem seus despachos e escritos de caráter científico-filosófico, além da narrativa do desenvolvimento de suas atividades e ideias, fixadas em diários e na vasta correspondência com diversas personalidades do campo da ciência na época. Entretanto, como testemunha melancolicamente o próprio Goethe, essa atividade permaneceu, de certa forma, à sombra de seus textos literários:

Há muito mais de meio século, as pessoas me conhecem, em meu país natal e também no estrangeiro, como poeta e assim me têm apenas como tal; que eu tenha com constante afinco e com grande atenção me dedicado à natureza em seus fenômenos físicos e orgânicos de uma forma geral e 
que de forma tranquila me esforcei por fazer com seriedade observações de modo contínuo e apaixonado, isso não é tão levado em conta e muito menos ainda com a devida atenção. (Goethe. "História dos meus estudos botânicos”. HA, v.13, p.167)

Uma das mais notáveis características de Goethe era o especial apreço pela experiência, tanto no campo do fazer literário como no do científico e burocrático. Era a partir dela, da observação direta e imediata de objetos e fenômenos, que desenvolvia suas teorias acerca das plantas, dos animais, das cores, abarcando áreas do conhecimento que, em sua maioria, ainda não se haviam estabelecidas como disciplinas autônomas na época como botânica, biologia, morfologia, zoologia, osteologia, física, química, meteorologia, mineralogia, geologia, anatomia, antropologia, arqueologia, psicologia, filosofia, arquitetura, música, além, claro, de seu notório interesse pela arte e pela crítica literária. O volume dos objetos colecionados por Goethe também nos ajuda a dimensionar a amplitude de seus interesses: só o inventário dos livros de sua biblioteca particular chegou à contabilização de 5.424 títulos, distribuídos em cerca de seis mil volumes. Começou a colecionar objetos tão logo teve início seu interesse por temas de caráter científico, em torno de 1770, com sua colaboração com Lavater, ${ }^{6}$ a pedido deste, para participar de estudos fisionômicos. Goethe reuniu desenhos de perfis de determinadas personalidades da época e de amigos, confeccionados a partir da projeção da sombra do semblante, perfazendo um total de mais de 1.200 silhuetas. Também colecionou manuscritos de várias pessoas para, através da grafia delas, traçar determinadas características de suas personalidades em busca de um maior entendimento do ser humano a partir de características físicas ou palpáveis. Assim diz Goethe em uma carta a Friedrich Heinrich Jacobi ${ }^{7}$ ( 10 maio 1812):

As folhas que recebi me são de um valor inestimável; pois a contemplação por meio dos sentidos é completamente imprescindível para mim, assim excelentes pessoas se tornam presentes para mim de uma maneira mágica através de suas grafias. Tais documentos de suas existências são para mim, além de algo tão caro, como um retrato, pelo menos um desejável substituto ou equivalente deles mesmos. ${ }^{8}$

A portentosa e variada coleção particular de arte de Goethe reunia obras de Rembrandt, Rubens, Veronese, Tintoretto, Bernini, Watteau, Cranach e Altdorfer, além de desenhos de Tischbein, Oeser, Chodowiecki, Schinkel e Cornelius que alcançam a soma de 26.500 objetos, incluindo gravuras, entalhes, esculturas de distintos tamanhos, desde as mais pequenas a colossais exemplares, que ornamentavam sua casa. A coleção de objetos de cunho natural-científico foi iniciada em 1780 e foi sendo renovada e aumentada até o ano de sua morte em 1832, compondo um arsenal de 23 mil peças. Tinha catalogado em seu escritório 17.800 exemplares de minerais, tipos de granitos, fósseis de animais e plantas; 200 exemplares de folhas; 200 frutos e sementes, além de exemplares de tipos de madeiras; diversos crânios e esqueletos de pequenos animais (sobre- 
tudo pássaros). Dessa coleção faziam parte objetos de interesse arqueológicos de variadas épocas - da Pré-história, da Antiguidade, do tempo dos romanos e germanos e da Idade Média. Havia objetos usados para fazer fogo, machados, vasos, colares, pulseiras, fivelas de cabelo etc.: "Através de sua visão sobre os achados, Goethe estava no ápice do conhecimento de sua época" (Wolfgang Timpel, in Jeßing; Lutz. Wild, 2004, p.376). Esses objetos, em conjunto com as relações que Goethe estabeleceu com distintos artistas e cientistas e além das experiências colhidas em diversas viagens, se acham relacionados de forma direta com seus escritos tanto acerca da arte como aqueles que intencionam expor seus pensamentos sobre ciência.

Em relação aos textos de cunho científico, Goethe publicou em vida o Estudo sobre a metamorfose das plantas (1790); Contribuições sobre óptica (17911792); Doutrina das cores (1810; 2 volumes). Além desses, também divulgou em duas séries de cadernos, intituladas Sobre morfologia e sobre ciência da natureza em geral, seus textos mais importantes sobre ciência natural entre os anos 1817 e 1824, assim como alguns estudos escritos décadas antes e várias poesias inspiradas em seus pensamentos sobre a natureza. ${ }^{9}$ Outros textos foram publicados postumamente logo após sua morte como complemento à ultima edição revista pelo autor de suas obras completas (Ausgabe letzter Hand), editados por seus secretários Johann-Peter Eckermann e Friedrich Wilhelm Riemer (volumes 50 a 60 ), entre os anos 1832 e $1842 .{ }^{10}$

Nos anos seguintes, mais duas edições completas da obra de Goethe foram editadas, ${ }^{11}$ até que com a morte do último herdeiro, seu neto Walther Goethe, os direitos autorais foram transferidos para o ducado de Weimar, cuja regência estava a cargo da grã-duquesa Sophie von Sachsen, sob cujo incentivo e financiamento se iniciou a primeira edição completa das obras de Goethe, levando em conta os manuscritos originais do autor e a última edição revista por ele. ${ }^{12}$ Para tanto foram convidados dezenas de especialistas para se responsabilizarem pela organização da empreitada, formando-se ao longo dos anos diversas equipes de trabalho. Entre os anos 1887 e 1919, vieram a lume os 143 volumes divididos em quatro seções: literatura, ciências naturais, diários e cartas, ${ }^{13}$ compondo a chamada Edição de Sofia (Sophien-Ausgabe) ou Edição de Weimar (Weimarer Ausgabe),${ }^{14}$ que se tornou a edição mais ampla das obras de Goethe, permanecendo durante muitas décadas como a mais abalizada referência em pesquisas, devido ao empenho filológico na transcrição dos manuscritos. ${ }^{15}$ Entretanto, conforme aponta Dieter Borchmeyer (1989), o pretenso esmero editorial durante os 32 anos de execução sofreu ingerências de vários tipos, inclusive a proibição da publicação de textos de Goethe de seus Diários (Tagebücher) de acentuado caráter erótico, sendo algumas vezes "amenizados" com sobrescritos e rasuras pelas damas da corte da grã-duquesa.

A edição dos textos de cunho natural-científico seguiu carreira solo sob os auspícios da Academia Alemã Leopoldina dos Cientistas Naturais (Deutsche 
Akademie der Naturforscher Leopoldina), hoje Academia Nacional das Ciências (Nationale Akademie der Wissenschaften). Fundada em 1652 e situada nos dias de hoje na cidade de Halle, é a mais antiga academia de ciências do mundo por sua duração ininterrupta e dela também Goethe tomou parte, eleito membro em 1818 sob o nome secreto de Arion IV. Nesta época era presidente da academia Christian G. D. Nees von Esenbeck (1776-1858) que manteve com Goethe entre os anos de 1807 e 1830 uma ativa correspondência. ${ }^{16}$ Esenbeck em conjunto com Philipp von Martius concederam a designação Goethea ${ }^{17}$ a uma planta originária da mata atlântica, coletada por Martius em Ilhéus durante viagem científica entre os anos 1815 e 1817, empreendida pelo príncipe Maximilian Wied-Neuwied. ${ }^{18}$ Assim comunica o botânico a Goethe em carta de 1821 a homenagem:

Ousei dar esse nome querido, que vive em tantos corações, a um gênero de planta porque faz muito bem ao botânico poder dirigir-se simbolicamente aos corifeus e fomentadores de sua ciência em meio a plantas viçosas e vê-los como que verdejantes e florescentes diante de si. Que Vossa Excelência não considere essa malvácea inteiramente indigna de vosso nome! Ela representa um gênero seguro, muito bem fundamentado, de plantas sul-americanas, talvez principalmente brasileiras e num futuro próximo deverá ganhar ainda significativa expansão em novas espécies. (Esenbeck, apud Mazzari, 2010 $)^{19}$

Os dois presidentes subsequentes da Academia, Dietrich G. Kieser e Carl August Carus, também demonstraram interesse pela obra científica do poeta. Kieser era desde 1812 professor de medicina em Jena e frequentemente visitava Goethe. Com Carus, médico e pintor, manteve correspondência, versando sobre temas científicos e artísticos.

O início do trabalho de edição dos textos de Goethe pela Academia Leopoldina remonta aos anos 1930. O primeiro volume da série foi publicado em 1947 e tem como previsão de publicação do $28^{\circ}$ volume abril de 2019 , o que finaliza a portentosa iniciativa. Essa edição se destaca pelo esforço intelectual que se estendeu por mais de sete décadas e teve como ideia central a realização de uma nova edição com viés histórico-crítico acrescida de comentários, destinada não apenas a cientistas, mas ao público em geral interessado na obra de Goethe. Foi gestada inicialmente pelo químico e físico Karl Lothar Wolf (1901-1960) com o apoio de Leiva Petersen (1912-2002), representante da editora Hermann Böhlaus Nachfolger de Weimar. A eles se somaram o botânico Wilhelm Troll (1897-1978) e o biólogo, químico e geólogo, Günther Schmid (1888-1949), responsáveis pelos primeiros volumes da coleção que, após os anos 1950, passaram a contar com a editoria de Rupprecht Mathaei (fisiólogo; 1895-1976), Dorothea Kuhn (química; 1923-2015), Wolf von Engelhardt (geólogo; 19102008) e Irmgard Müller (médica e farmacêutica; 1938). ${ }^{20}$ Como resultado desse longo trabalho passa-se a ter à disposição a primeira edição na qual são reunidos, em sua totalidade, os textos de temática científica de Goethe, ${ }^{21}$ que perfazem 
um total de 16.783 páginas, sendo 4.125 de lavra de Goethe, acrescidos de 450 ilustrações, firmando-se como um contraponto à Edição de Weimar, claramente associada ao positivismo reinante no início do século XX. ${ }^{22}$ Os milhares de páginas escritas por Goethe, dispostas em ordem histórica, proporcionam ao pesquisador uma fonte segura de consulta e levam o leitor ávido de conhecer o pensamento goetheano acerca dos mistérios da natureza a observar sua gênese e desenvolvimento. De forma resumida, apresentaremos a seguir a jornada de Goethe em busca de revelar o que se escondia sob o véu de Ísis.

\section{Goethe e os estudos da natureza: forma, imagem e formação}

Sob mil formas podes te esconder.

Entretanto, muitíssimo amada, logo te reconheço;

Podes cobrir-te com véus mágicos,

Onipresente, logo te reconheço.

(Goethe, "Divã Oriental-Ocidental”, HA 2, p.88)

In tausend Formen magst du dich verstecken,

Doch, Allerliebste, gleich erkenn' ich dich;

Du magst mit Zauberschleiern dich bedecken, Allgegenwärt'ge, gleich erkenn' ich dich.

Antes de seguirmos adiante na exposição de alguns conceitos basilares da ciência goetheana, cumpre esclarecer o que se intencionou ao aludir no final do capítulo anterior à imagem metafórica do "véu de Ísis". Essa menção se relaciona diretamente com a gravura que ilustra a dedicatória feita por Alexander von Humboldt a Goethe em seu livro, Ideias para uma geografia das plantas (Ideen zu einer Geographie der Pflanzen). Editado em 1807, ali estavam expostos os pensamentos que Humboldt teceu a respeito da vegetação, da geografia e sobre os povos da América Central e do Sul durante a longa viagem que empreendeu entre os anos 1799 e 1804 . A gravura talhada em cobre a partir de um desenho do escultor dinamarquês Bertel Thorvaldsen (1770-1844), nos apresenta uma alegoria recorrente na época. A imagem, encoberta por um véu, reúne em uma única representação duas figuras míticas, a deusa egípcia Ísis e a deusa grega Ártemis, associadas ao mundo desconhecido da natureza. O gesto de remover o véu da deusa indica a apropriação desses conhecimentos, revelando-se assim a natureza para aquele que o retira. Entretanto, a gravura nos diz muito mais do que simplesmente aludir ao empenho cientificista da época. Ela nos informa a respeito dos conceitos que nortearam Humboldt em suas observações e sua estreita ligação com o pensamento de Goethe acerca da natureza. A reunião dos mitos de Ísis-Ártemis (natureza) com o de Apolo (arte) portando sua lira e o gesto de retirar o véu com a menção direta ao livro de Goethe, Metamorfose das plantas, que está no chão entre eles, remete à reunião conceitual entre natureza e arte. 


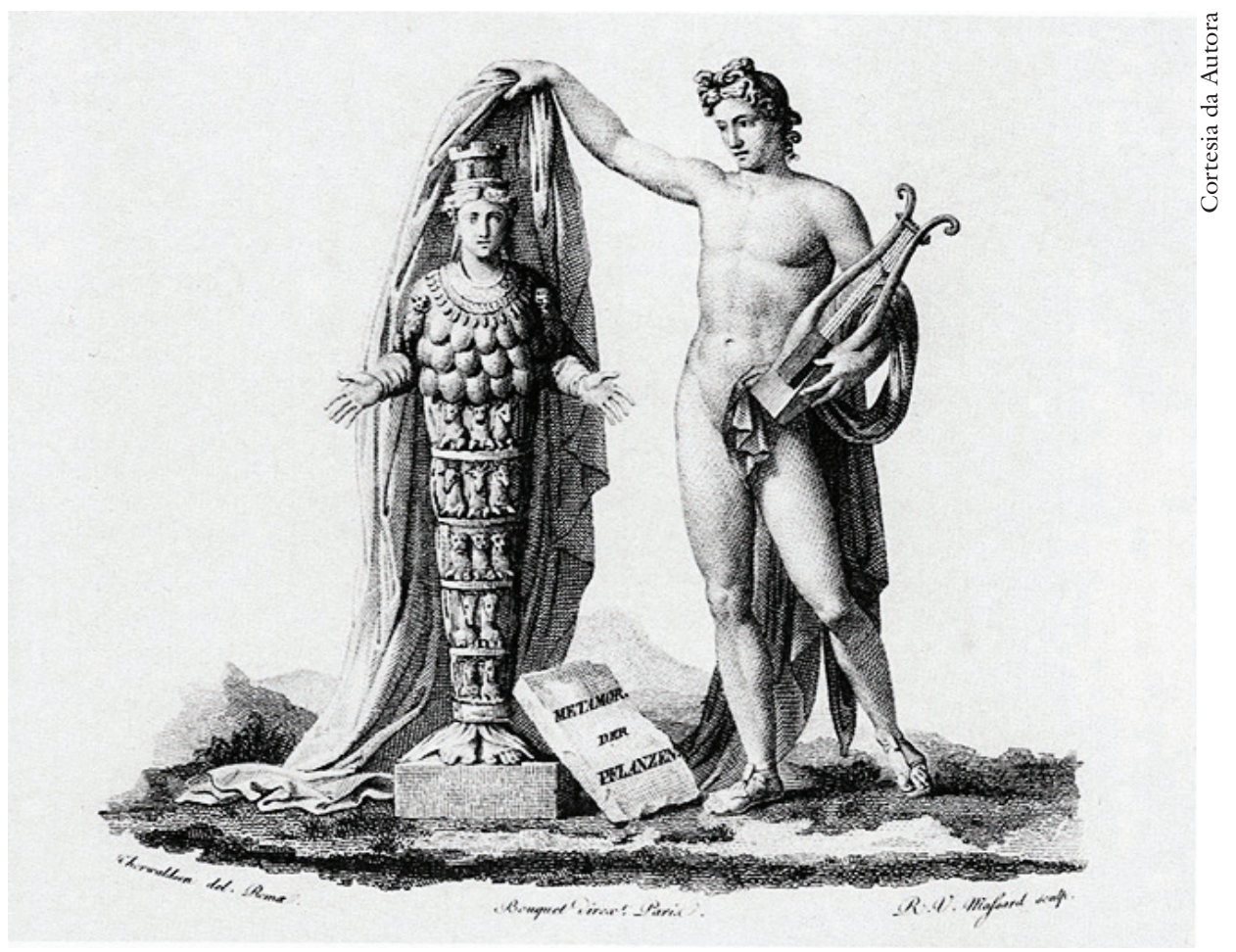

Figura 1 - Apolo desvela Ártemis. ${ }^{23}$

Fundamental para que se possa entender como se teceu a trama conceitual goetheana, esse "olhar estético" dirigido às formas da natureza procurava entender o mundo natural como um todo em constante interdependência. Olhar as singularidades fenomênicas da natureza como integrantes de um todo, tem como pressuposto uma ideia de natureza como um gigantesco quadro com suas partes em correlação. O conceito de totalidade é a base de toda a ciência do "Wolfgang Apolo", conforme Heine se referiu uma vez a Goethe. ${ }^{24}$ Esse conceito marca a diferença em relação a uma concepção de ciência que cada vez mais se especializava, estudando cada singularidade distanciada de uma organicidade. A morfologia de Goethe, assim como sua visão acerca do mundo animal e da natureza de modo geral, se configura em um modo de ver o mundo envolvido em uma dinâmica constante, no qual cada elemento não pode ser comtemplado sem estar em relação ao todo, assim como a composição de uma pintura coloca em relação entre si os diversos elementos constitutivos e que, a partir dessa relação, constituirão o todo da obra. Para Goethe, não só os elementos internos estão em relação entre si, como também se relacionam interior e interior : "reconhecer as formas viventes como tais, conceber suas partes exteriormente visíveis e tangíveis em interdependência, admiti-las como indícios do interior e assim, de certa forma, dominar o todo na contemplação" (Goethe, MA, v.12, p.13).

Comparando a imagem anterior com a seguinte, pode-se resumir a distinção entre a ciência goetheana e a que passou a viger até os dias de hoje. 


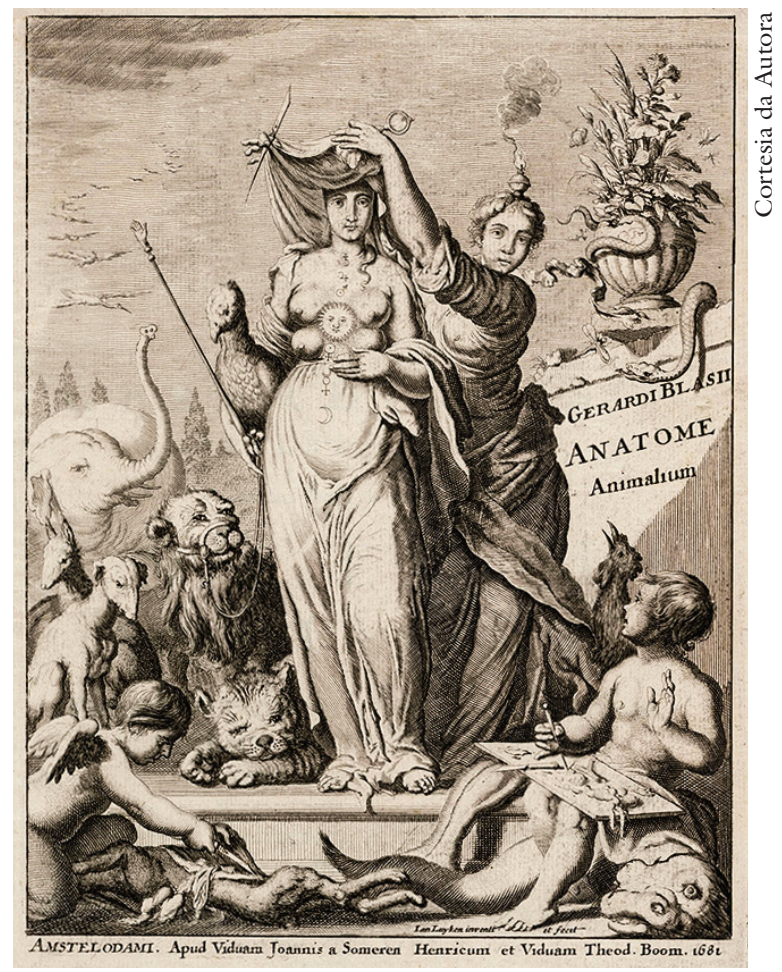

Figura 2 - Ísis revelada pela ciência. ${ }^{25}$

As duas imagens remetem à diferença de ponto de vista que possuía Goethe, assim como Humboldt, em relação à vertente da ciência do século XVIII, que se consagrou como a ciência conforme a entendemos hoje, baseada em um discurso racional, materialista e extremamente apegado a particularidades. A dessacralização contínua da natureza através da metodologia experimental, assentada em princípios matemáticos e mecanicistas, estava bem distante do ideal almejado por Goethe. Em contraponto a um princípio estético, conforme defendido por Goethe e assumido por Humboldt, estabeleceu-se um princípio científico, separando os dois domínios do fazer humano. Apolo foi, assim, substituído pela ciência.

Procurar uma escrita linear nos textos de Goethe dedicados ao conhecimento dos fenômenos da natureza, escrita objetiva e clara é tarefa inglória. Suas ideias se encontram revestidas de um complexo pensamento filosófico-teológico que se enredam com suas teorias estéticas. Portanto, para que se possa trilhar o caminho de Goethe pelo mundo, faz-se necessário ter em mente alguns conceitos basilares de sua teoria acerca da natureza. Para ele, não será apenas o olhar do cientista que permitirá entender a natureza e, assim, dar ciência do que existe no "âmago das coisas do mundo", como quer o melancólico Fausto que vê frustradas todas as suas tentativas de obter o entendimento das razões do mundo. $\mathrm{O}$ que concederá acesso à natureza é o olhar interessado daquele que procura ver as formas com as quais o mundo da natureza se reveste e como essas formas se inter-relacionam. 
Goethe intenciona criar uma maneira de explicação do mundo com um olhar de um artista que abarca o todo, como os limites da tela formando um universo no qual os elementos ali representados formam uma totalidade em diálogo, em interna correspondência. Ele integra uma plêiade de pensadores que tentam fazer valer no mundo pós-iluminista da passagem do século XVIII para o XIX, ou seja, na aurora do mundo mecanizado, uma "abordagem estética da natureza", valendo-nos aqui de uma formulação de Pierre Hadot (2006, p.284). Assim como Goethe, outros como Rousseau, Schiller, Kant, Schelling e os românticos alemães, sobretudo, Novalis, partidarizam do empenho do filósofo Alexander Gottlieb Baumgarten (1714-1762) de postular, como alternativa a uma "veritas logica", uma "veritas aesthetica" que se alcançaria através de um modo artístico de ver a natureza. Sob esse ponto de vista, a natureza não seria um mero objeto ao qual a razão se dedicaria para alcançar o entendimento acerca dela. À vontade de conhecer e de revelar os profundos segredos de modo investigativo é acrescida uma outra atitude: a de promoção de um envolvimento também do sensual. Para Hadot (2006, p.285), tem lugar "a superação da curiosidade com relação aos segredos da natureza em proveito de uma experiência afetiva, que invade todo o ser e consiste em se experimentar como parte do Todo". Nisso reside o que se pode chamar de um "panteísmo sensorial". O modo de ver o mundo de Goethe ao se basear no todo e não nas partes faz-se de acordo com uma visão de mundo panteísta, sobretudo conforme apresentado pela expressão de Espinosa: "Deus é natureza". Heine ao resumir a história da filosofia alemã, concede a Goethe mais alguns epítetos, além de o "grande pagão", o considera como o "Espinosa da poesia", sobretudo em referência a seus poemas de juventude: "Todos os poemas de Goethe serão imbuídos do mesmo espírito que exala dos escritos de Espinosa" (Heine, 1991, p.109). ${ }^{26}$

Dessa forma, a visão estética da natureza alcança um outro patamar, o de se revestir de um sentimento religioso que vê a natureza não como uma coleção de exemplares, mas sim como um organismo vivo em constante mudança, daí o conceito de metamorfose ser determinante no corpus conceitual de Goethe. A partir da visão de uma natureza que vive em constante mudança, ele se porá distante de um empreendimento que visa apenas à catalogação de espécimes, conforme estabelecido, por exemplo, pelo pesquisador da natureza sueco Carl von Linné através de suas obras Systema Naturae e Species Plantarum (1735-1753), nas quais propõe um sistema de catalogação, usado até hoje, dos espécimes do mundo animal e vegetal conhecidos até então:

Por ora, porém, eu tenho que reconhecer que, depois de Shakespeare e Espinosa, a maior influência exercida sobre mim foi a de Linné e, aliás, justamente pelo conflito que ele me provocava. Pois, na medida em que procurava adotar em mim suas brilhantes e perspicazes distinções, suas acertadas e oportunas leis, ainda que frequentemente arbitrárias, em meu interior tinha lugar um dilema: aquilo que ele procurava manter em separado por meio da força, eu, de acordo com a mais íntima necessidade do 
meu ser, tinha que me esforçar para unificar. (Goethe. Geschichte meines botanischen Studiums, 1817. HA, v.13, p.58)

A ordenação arbitrária de Linné auxiliou Goethe a desenvolver uma mirada mais exata para os fenômenos, em especial sobre o mundo das plantas, mas não com a finalidade de catalogação ou como desenvolvimento de um apuro pelas singularidades, mas sim para buscar parentesco entre os diversos elementos do mundo natural, para ver como os diversos elementos, enquanto seres viventes, se comportam em inter-relação. O olhar dirigido à catalogação tem de ser exato para se poder identificar minuciosamente as peculiaridades de cada exemplar que se intenta identificar. Entretanto, segundo Goethe, a essência só pode ser almejada na medida em que se observa o exemplar em seu estado natural, ou seja, na própria natureza.

Dedicar-se ao objeto natural tem para Goethe um significado sutilmente diverso do que o disposto por Linné e que torna despropositada a ideia de que a natureza tenha um véu. Segundo Hadot (2006, p.275): "Não há oposição entre o fenômeno e o que se ocultasse no fenômeno". Se existe um véu, conforme a teoria de Goethe, ele cobre nossos olhos, e não a natureza que pode revelar a nós seu interior, seus segredos profundos, através da forma exterior de modo imediato.

Quando percebemos os objetos da natureza, especialmente os viventes, desejamos proporcionar uma visão do conjunto de seu ser e de atuar, de tal maneira que cremos poder melhor alcançar tais conhecimentos mediante a decomposição de suas partes; de fato, esse caminho nos leva bem longe. [...] Mas esses esforços analíticos, permanentemente continuados, também produzem algumas desvantagens. [...] Por isso, também nos homens de ciência de todos os tempos, surgiu um impulso de conhecer as formações viventes enquanto tais, de conceber suas partes externas tangíveis em inter-relação, de tomá-las como indicações de seu interior e assim dominar, até certo ponto, a totalidade pela intuição. $\mathrm{O}$ quão próximo essa aspiração científica está em correlação com a arte e com o impulso de imitação, não se precisa por ora detalhar. (Goethe. "Introdução ao objetivo". HA, v.13, p.54)

Nesse pequeno trecho do artigo, escrito em 1807 e publicado uma década depois nos "Cadernos sobre morfologia" (1817), Goethe sintetizou alguns pontos que norteavam o desenvolvimento de suas reflexões. Cumpre ressaltar que os textos sobre ciência de Goethe se diferenciam dos textos de lavra de cientistas. Sem dúvida alguma, a marca do poeta, aliada à complexidade de seus pensamentos, muitas vezes requer uma leitura interpretativa que, de certa forma, coincide com aquilo que ele mesmo propõe em relação à natureza: "Por isso, no desenvolvimento da arte, do saber e da ciência, são encontradas variadas tentativas de fundamentar e desenvolver uma teoria que gostaríamos de chamar de Morfologia" (Goethe, HA, v.13, p.55). Haveria, assim, tanto uma arte como uma ciência ligada às formas. 
A proximidade da "aspiração científica" com a arte ultrapassa a questão da visão do todo e se reveste de uma linguagem que procura manter e reproduzir a própria vivacidade da natureza. O que se percebe nesse texto é que o importante para ele, e ousado em termos de postura científica, se dá na própria intenção de suas investigações: a apreensão do fenômeno da vida em cada circunstância em que ele se dá. Vida que em cada episódio da natureza plasma o exterior de acordo com seu interior e que está sempre em desenvolvimento, em constante mutação. Daí a necessidade de um pensamento capaz de manter na observação esse mesmo aspecto de mutabilidade, de duração no tempo. Remetendo ao que Espinosa cunhou como natura naturans em contraposição à natura naturata, Goethe expõe a distinção entre Gestalt (forma) e Bildung (formação):

O idioma alemão tem a palavra Gestalt [forma] para designar a complexidade da existência de um ser real. Por meio desse termo ele abstrai o que é móvel, ele admite que algo que se inter-relaciona seja identificado, tornado algo em si fechado e que sua característica seja fixa.

Mas se observarmos todas as Gestalten [formas], em especial as orgânicas, então descobriremos que em lugar algum surge algo permanente, nada está em repouso, nada é terminado, pelo contrário, tudo oscila em um contínuo movimento. Por isso nossa língua utiliza a palavra Bildung [formação] para designar tanto aquilo que já foi produzido, como o que virá a ser.

Se queremos introduzir uma Morfologia, então não podemos falar de Gestalt [forma]; mas sim, caso utilizemos a palavra, que pensemos apenas na ideia, no conceito ou em algo que se fixa por meio da experiência apenas por um instante. (Goethe, HA, v.13, p.55)

Assim como a natureza está em eterno devir, gerando formas, a maneira de observar os fenômenos naturais deve plasmar um "pensar vivente". A contemplação dos fenômenos da natureza, a observação minuciosa das formas exteriores, conduz ao conhecimento das leis de formação através do despertar na consciência do pesquisador da intuição (Anschanung): "Aquilo que tomou forma será novamente transformado e caso queiramos, de certa maneira, alcançar uma intuição vívida da natureza, então teremos que nos manter tão móveis e plásticos, de acordo com o modelo que ela mesmo nos dá" (Goethe, 2000, v.13, p.56). O que para a ciência contemporânea pode se aproximar do que se chama ciência holística, para a época significava algo inusitado devido à concepção dominante que estabelecia como regra geral da natureza a lei de causa e efeito, que criava uma natureza segundo "necessidades mecânicas" (Weiszäcker, 2000, p.543). Também não havia se estabelecido uma ciência segundo o ponto de vista evolutivo, o que já se distinguia no pensamento goetheano:

Podemos dizer, pois, que as criaturas que, emergindo pouco a pouco de uma afinidade quase indistinguível como plantas ou como animais, se aperfeiçoam em duas direções opostas, de modo que a planta, por fim, se glorifica de forma duradoura e rígida como árvore, enquanto o animal o 
faz através do homem, alcançando a mais elevada mobilidade e liberdade.

(Goethe, HA, v.13, p.58)

Ao propor uma Morfologia, Goethe intentava estabelecer uma ciência baseada no apuro dos sentidos, destinados a apreender o próprio movimento gerador da vida. Mas essa objetividade no ato de observação não pode prescindir da mediação da razão, conforme disposto nos seguintes versos: "Nos sentidos tens depois de confiar; / Nada de falso eles te fazem ver / Se a tua razão te conservar desperto. / Com vivo olhar observa alegremente, / E percorre, a passo firme e dúctil, / Os espaços de um mundo repleto de riquezas". ${ }^{27}$ As leis, as ideias, as teorias são subjacentes aos fenômenos, elas se manifestam de forma visível neles mesmos: "Não se deve procurar nada por trás dos fenômenos: eles mesmos são a teoria" (Goethe, Maximen und Reflexionen, No. 488). Dessa forma, Goethe propõe um entendimento singular do ato de percepção.

Em seu texto basilar sobre o conceito de experiência, "O experimento como mediador entre objeto e sujeito" (1792), ${ }^{28}$ Goethe estabelece uma importante fronteira no modo de relação entre sujeito e objeto durante a execução de um experimento, ou de uma sequência de experimentos, conforme já se pode identificar através do próprio título do texto. Ele afere ao experimento um caráter singular e distinto da usual dinâmica dos métodos experimentais que comumente desconsideram o sujeito em nome de uma imparcialidade e objetividade do processo, com a desconsideração de tudo que possa parecer subjetivo, objetivando-se uma "renúncia" à subjetividade (ao que agrada ou que não agrada):

Um desafio ainda maior aguarda aqueles que, inflamados pelo impulso de conhecer os objetos da natureza, passam a observá-los em si, e com cada outro, pois perdem a medida que os ajudava quando, como homens, olhavam para o objeto somente em relação a si mesmos. [...] devem buscar e investigar o que é e não o que agrada. [...] No momento em que observamos um objeto em relação a ele próprio e aos demais objetos, e imediatamente não o desejamos nem o rechaçamos, então, com atenção silenciosa, logo seremos capazes de conceber um conceito claro a respeito dele, de suas partes e suas relações. (Goethe, 2011, p.118)

Goethe propõe um processo duplo no ato de conhecimento. Ao mesmo tempo em que se investiga o mundo, deve-se estar atento ao próprio processo de conhecimento, de como esse se dá pelo sujeito investigador, pelo sujeito que faz a experiência.

Somente quando o observador usa sua força de julgamento para provar ocultas relações da natureza; quando ele, num mundo em que também está só, está atento a cada passo para resguardar-se de toda precipitação, e mantém-se firme em seu propósito, sem, no entanto, deixar-se levar por circunstâncias desapercebidas, úteis ou prejudiciais, ao longo do caminho; e, por fim, quando ele, não se deixando controlar facilmente por ninguém, pode ser seu mais arguto observador e desconfia de si mesmo através de seus ardentes esforços, então cada um pode bem ver quão severas são essas 
exigências e quão pouco pode ter esperança de vê-las plenamente satisfeitas. Sejam elas feitas sobre outros ou sobre si. (Goethe, 2011, p.119)

Ao mesmo tempo em que rejeita a subjetividade em termos de "atração ou repulsão" em relação ao objeto, Goethe adjudica um papel preponderante à consciência que só pode ser ativada pela vontade do sujeito: "Tampouco se pode negar que é o mais alto e o mais independente poder criativo da alma que se apropria, combina, ordena e desenvolve a experiência" (ibidem, p.120). O cientista, assim como o artista, geram processos, ativam a criação.

O desenvolvimento da experiência leva o sujeito à observação, que é um ato de consciência: "Eu me arrisco a afirmar que um experimento, ainda que interligado a outros, não prova nada, e que não há nada mais perigoso que querer provar qualquer afirmação imediatamente através de experimentos" (ibidem, p.125). A Goethe, o desenvolvimento da capacidade de observação, da duradoura consciência do ato de conhecimento, torna-se peça-chave nesse duplo processo em que o conhecer o mundo resulta na tomada de consciência de si mesmo. A ciência requer um interesse associado à consciência do ato de construção do conhecimento, o que se poderia interpretar como uma Bildung, um aperfeiçoamento do sujeito cognoscente: "Cada experiência que nos ocorre, cada experimento que a repete são, na verdade, uma parte isolada do nosso conhecimento, e através de repetições frequentes esse conhecimento isolado é trazido à consciência" (ibidem p.125). O exercício da observação acabaria, pois, por criar "um novo órgão" no homem, conforme se refere Alexander von Humboldt acerca de si mesmo:

Nas florestas do rio Amazonas, como nas cordilheiras dos elevados Andes, reconheci, como animada de um polo a outro por um sopro, apenas uma vida que está derramada em pedras, plantas, animais e no túrgido peito do homem. Por toda a parte eu estava traspassado dos sentimentos, como aquelas relações em Jena poderosamente me influenciaram, como eu, elevado pelo modo de ver a natureza de Goethe, fui, por assim dizer, equipado com novos órgãos. (carta a Caroline von Wolzogen de 14 maio 1806; apud Bruhns, 1872, p.418)

A adjudicação de tamanha confiança na força da alma, do intelecto, de plasmar através da observação um órgão que seria responsável de descortinar os aparentes segredos da natureza, baseia-se na certeza difundida por Goethe de sinonímia entre o mundo exterior e o mundo exterior, das forças plasmadoras do mundo e das forças que levam ao seu entendimento. Há em Goethe, apesar de toda sua objetividade experimental, um idealismo que o leva a estabelecer um elo religioso com a ciência:

Tudo aquilo que, no mais alto sentido, chamamos de inventar, descobrir, é o significativo exercício, a confirmação de um sentimento original de verdade que, formado silenciosamente há bastante tempo, sem se fazer notar, conduz com a velocidade de um raio a um conhecimento produtivo. É 
uma revelação desenvolvida a partir do interior para o exterior que permite ao homem pressentir sua semelhança com a divindade. É uma síntese de mundo e espírito, a qual concede a mais bem-aventurada segurança acerca da eterna harmonia da existência. (Goethe, Maximen und Reflexionen, n.364, HA v.12, p.414)

Aqui se faz ouvir não só a influência das ideias de Espinosa como as de Johann Gottfried Herder, expressando uma concepção de natureza como manifestação do divino e, assim, o empenho científico se reveste de um empenho pela verdade. $\mathrm{O}$ fiel da balança que regula a porção de subjetividade e objetividade contida na ciência há de ser primeiro aferido para se garantir a veracidade dos fatos apurados. O sentimento de verdade (Wabrheitsgefübl) em relação àquilo que se percebe, tanto advindo do mundo interior quanto do mundo exterior, precisa ser ajustado por uma concepção que una homem, Deus e natureza (mundo) para que se possa fazer ciência. Somente ao se fazer mundo, o sujeito pode verdadeiramente compreendê-lo, conforme expressa em um aforismo de 1795: "É uma agradável ocupação investigar simultaneamente a natureza e a si mesmo, não exercer violência contra ela, nem contra o espírito humano, e sim colocar ambos em equilíbrio através de uma doce influência recíproca" (Goethe, Maximen und Reflexionen, n.248, HA v.12, p.434).

Segundo Wyder (1999, p.16), no processo descrito por Goethe de conhecimento do mundo, o homem experimenta junto ao exterior da natureza, a expressão de uma divindade que está em seu próprio interior e, ao observar essas formas e os fenômenos, se adquire "uma confirmação de seu próprio íntimo que ultrapassa bastante aquela pura satisfação intelectual". Portanto, é inerente à ciência goetheana o desenvolvimento de uma ética que garanta um resultado "verdadeiro": "é fácil ver o perigo que se corre quando se interliga uma experiência singular a uma ideia preconcebida ou a algum tipo de relação que não é inteiramente sensível, e tenta-se confirmá-la através de um único experimento, quando antes o poder da imaginação do espírito já a anunciou" (Goethe, 2011, p.126). O cientista para comprovar o resultado de sua observação deve descrever o processo sob "diversas perspectivas" (ibidem, p.130), apresentar as várias facetas de uma "mesma experiência". Dessa maneira ele pode se esquivar de encontrar ideias preconcebidas como resultado: "Na contemplação da natureza, quer no grande como no pequeno, sempre me coloquei a pergunta sem interrupção: é o objeto ou és tu, que se manifesta aqui? E, nesse sentido, observava também predecessores e colaboradores" (Goethe, Maximen und Reflexionen, n.513, HA v.12, p.435). A consciência de si surge através da negação da subjetividade enquanto produtora de afetos de mera atração e repulsão: "Os erros do observador nascem das peculiaridades do espírito humano. $\mathrm{O}$ ser humano não pode e não deve descartar nem negar suas peculiaridades; mas pode formá-las e dar-lhes uma direção" (Goethe. "Observar e pensar", 2012, p.67). Essa duplicidade de despertar a consciência de si no processo de conhecimento dota a ciên- 
cia goetheana de um dinamismo que aproxima o sujeito cognoscente no ato de conhecimento com a vivacidade dos objetos da natureza, que estão interligados e sempre vivos em mudança.

$\mathrm{O}$ apego de Goethe à realidade dos fatos através da observação não faz dele um absoluto "realista" e "empirista", ${ }^{29}$ pelo contrário. Pode-se bem falar de uma relativização da empiria em prol do conteúdo ideal: "Caso se pense nos resultados desses experimentos, vê-se que, por fim, tem de se terminar a experiência, ocorrer a intuição (Anschanen) daquilo que se forma (Werdendes) e a ideia tem de, por fim, se manifestar (Goethe, Morphologie, 1795; MA 4.2, p.191). Temos então apontadas aqui as três instancias do processo de conhecimento: experiência - intuição - ideia. Segundo Wyder (1999, p.18 ), "a intuição deveria, portanto, atuar conciliadoramente entre dedução e indução como processo de conhecimento, ou em termos de conceitos de Goethe: entre ideia e experiência".

Em manuscrito de 1798, denominado de "Experiência e ciência" (Erfahrung und Wissenschaft), ${ }^{30}$ Goethe, ao informar sobre sua metodologia científica, estabelece a existência de um "ponto de vista superior" a ser almejado pelo pesquisador da natureza quando esse deparar com a impossibilidade de haver a constância de uma determinada "lei empírica" ao longo da realização de uma série de experimentos, lei essa que foi por ele deduzida a partir da observação dos experimentos. Os fenômenos surgem diante do pesquisador da natureza, primeiramente como "fatos", isolados e indeterminados, e são por ele analisados e ordenados, buscando "apreender e estabelecer a determinação dos fenômenos" (Goethe, 2012, p.73). Para se chegar a uma assim chamada "lei geral" que abarque todos os fenômenos indistintamente é preciso estar atento: "existem muitas falhas empíricas que é preciso eliminar para manter um fenômeno puro constante". Nesse ponto, Goethe introduz uma nova categoria conceitual, característica de seu pensamento natural-científico, a existência de um "fenômeno puro" (reines Phänomen), o qual não pode ser abarcado pelo pesquisador de forma sensitiva: "o observador jamais vê o fenômeno puro com os olhos" (ibidem). A procura por um ponto de observação superior que elimine a variabilidade para assim ter acesso ao princípio universal requer a eliminação de alguns aspectos empíricos: "sacrificar uma fração empírica à ideia do fenômeno puro" (ibidem). Esse ponto de vista que supera a contradição entre experiência e lei empírica é o que une o pesquisador ao objeto em seus aspectos mais universais, promovendo uma união estreita entre ambos: "Esse seria, pois, segundo minha experiência, o ponto em que o espírito humano mais se aproxima dos objetos em sua universalidade, trazendo-os para perto de si e podendo (como normalmente fazemos no empirismo comum) como que amalgamar-se com eles de uma maneira racional" (ibidem, p.74). O ápice que o pesquisador da natureza pode alcançar é ter a consciência do "fenômeno puro", "a derradeira meta de nossas forças", não se importando com as causas que provocam a manifestação do fenômeno, mas sim 
o que os regula de forma primeira, já que possui "unicidade e mutabilidade": "O fenômeno puro se apresenta, finalmente, como resultado de todas as experiências e experimentos". Cabe ao sujeito cognoscente executar as operações intelectuais (anímicas) para chegar até ele: “A fim de representá-lo, o espírito humano determina o que é empiricamente oscilante, exclui o casual, separa o impuro, desenrola o complicado - enfim: descobre o desconhecido" (ibidem, p.74). Aqui ressurge o que já foi apontado anteriormente, a maestria do observador para dominar o próprio processo de se obter conhecimento, processo este que, para Goethe, é de âmbito prático e não especulativo: "Em verdade este trabalho não deveria ser chamado de especulativo, pois no fim, ao que me parece, trata-se apenas das operações práticas e autorretificadoras do intelecto humano comum, que se atreve a se exercitar numa esfera superior" (ibidem).

Nessa última passagem, encontram-se dois elementos que merecem destaque. O tipo de ação que o intelecto humano desenvolve atende a duas ordens: uma prática e a outra ideal, o que se coloca em relação à seguinte máxima: "Existe uma suave empiria que se faz, o mais intimamente possível, idêntica ao objeto e, desse modo, se torna a própria teoria. Essa intensificação (Steigerung) da capacidade espiritual, porém, pertence a uma época altamente ilustrada" (Goethe, HA v.8, p.302). O que gostaríamos destacar é o processo de superação de si através do processo de intensificação. $\mathrm{O}$ apuro "autorretificador" que remete a um processo alquímico ${ }^{31}$ de purificação através de destilação, torna o sujeito mais próximo do conteúdo ideal que se manifesta fenomenologicamente no objeto. É o processo que faz que de nossos olhos seja retirado o véu. A pureza fenomênica do objeto só pode ser abarcada através da "purificação" dos órgãos do sujeito cognoscente, órgãos esses que já não são mais de ordem sensorial, mas sim de ordem espiritual ou intelectual. Esse será o tema da conversa entre Goethe e Schiller que marcará o início da amizade intelectual entre os dois.

O texto escrito por Goethe, "Acontecimento feliz" relata a conversa entabulada por eles na saída de uma palestra da Sociedade dos Cientistas Naturais de Jena em julho de 1794 e continuada na casa de Schiller, onde Goethe passa a relatar suas ideias acerca da metamorfose das plantas, valendo-se da pena para desenhar quando as palavras já não eram mais suficientes:

[...] foi então que expus a metamorfose das plantas com vivacidade e com alguns traços de pena expressivos fiz nascer sob seus olhos uma planta simbólica $[\ldots]$ quando acabei, abanou a cabeça e disse "Isto não é nenhuma experiência, isto é uma ideia". Eu fiquei perplexo [...] e repliquei: "Apraz-me muito ter ideias sem o saber e, além disso, vê-las mesmo com os olhos". (Goethe, 1993b, p.73)

Embora o tema da planta primordial seja de fulcral importância para Goethe naquele momento, a menção a ela só aparece em textos de caráter autobiográfico (como Viagem à Itália) ou em cartas, praticamente desaparecendo após a publicação de 1790 da Metamorfose das plantas. O que parece lhe substituir 
em termos de importância e relacionado aos estudos de botânica é sua ocupação com os princípios da própria metamorfose, conforme aponta Molder (1993, p.23): “O desaparecimento do termo [planta primordial] parece ter origem na necessidade de determinar mais exatamente a relação entre ideia e sensível, o modelo que pudesse estabelecer o ponto de reunião do ideal e do sensível".

Mais importante do que a fixação de um modelo, mesmo que ideal, o que parece ser de maior importância para o processo de conhecimento é a captação da dinâmica da criação de formas, daí a importância que passa a assumir não mais o modelo, mas sim o princípio originário das variadas manifestações que se dá a partir da metamorfose das formas de um modo geral, quer seja no caso das plantas, a planta originária, ou no caso dos animais, o tipo.

A morfologia repousa sobre a convicção de que tudo o que é tem também de se significar a si próprio. Admitimos este princípio desde os primeiro elementos físicos ate à exteriorização espiritual do homem. Nós voltamo-nos imediatamente para o que tem forma. O inorgânico, o vegetativo, o animal, o humano, tudo se dignifica a si próprio e aparece como o que é ao nosso sentido externo e ao nosso sentido interno. A forma é algo em movimento, algo que advém. Algo que está em transição. A doutrina da forma é doutrina da transformação. A doutrina da metamorfose é a chave de todos os sinais da natureza. (Goethe, Aufsätze, Fragmente, Studien. LA I, 10, p.128; apud Molder, 1993, p.27)

Não se trata de interpor premissas ou hipóteses para guiar o pesquisador no entendimento do mundo, o que se deve ter como foco são os objetos de interesse científico enquanto fenômenos ou formas diretamente em conexão com os sentidos humanos, tanto os que se voltam para o exterior como os que enfocam o interior do homem. Como algo em devir, a forma necessita de um processo de conhecimento que lhe seja parente. Assim como os objetos devem ser considerados segundo o processo de metamorfose, assim também a formação do pesquisador da natureza se dá de modo a que seus órgãos de apreensão do mundo sejam continuamente desenvolvidos. O processo fenomênico da metamorfose requer um pesquisador da natureza também dinâmico e em processo de transformação, pois a forma não perdura temporalmente, ela está em um progressivo estado de formação. Voltamos aqui a um ponto já mencionado anteriormente, ao do momento de apreensão do vivente, daquilo "que se fixa por meio da experiência apenas por um instante" (Goethe, HA v.13, p.55). Esse lampejo que ilumina e leva à compreensão das formas em sua vivacidade e também dos fenômenos só é possível pelo desenvolvimento no pesquisador da natureza do que Goethe caracterizou como o juízo contemplativo ou juízo intuitivo (Anschanende Urteilskraft).

Esse é o título de um pequeno texto de 1817, no qual discorre brevemente sobre a teoria filosófica de Kant em relação à sua, destacando o que lhe parece ser uma grande aproximação com seu próprio pensamento, nomeadamente 
o conceito de intelectus archetypus, contraposto ao intelecto discursivo, isto é, aquilo que em nós seria regido por leis lógicas. A Goethe incomoda a limitação dada por Kant à possibilidade do conhecimento por parte do sujeito: "nosso mestre limita seus pensadores a um juízo discursivo reflexivo, negando-lhes inteiramente um juízo determinante". Entretanto Goethe entrevê no próprio ideário do filósofo uma possiblidade de tal superação, citando o trecho que the é conveniente para fundamentar uma possiblidade de parentesco entre suas próprias concepções com as de Kant. Nesse trecho, Goethe alude ao fato do filósofo ora apresentar limites, ora apontar "para além dos limites que ele mesmo havia delineado". Goethe se propõe neste trecho a realizar uma tarefa que anos mais tarde assinalaria como tarefa da filosofia alemã: "Na filosofia alemã, ainda haveria duas grandes coisas a fazer. Kant fez a crítica da razão pura, um acontecimento incomensurável, mas que ainda não fechou o círculo. Falta agora que alguém capaz, notável, escreva a crítica dos sentidos e do entendimento humano e, caso isso seja feito com a mesma excelência, não teríamos muito mais a exigir da filosofia alemã" (Eckermann, 17 fev. 1829, p.312).

Goethe dizia não ter inclinação para filosofia; "para a filosofia propriamente dita, eu nunca tive uma predisposição particular" (Goethe, 2011, p.79). Por conseguinte, não levou a tarefa a cabo, não escrevendo nenhuma crítica, nem qualquer outro tipo de livro sobre o assunto. $\mathrm{O}$ que nos deixou foram vários pensamentos de cunho filosófico dispersos em pequenos textos, em aforismos e cartas, em suas memórias, em relatos de conversas feitos por alguns de seus secretários, em reflexões inseridas em romances e em poesias. A tarefa dos estudiosos que procuram entender suas postulações em relação à metodologia científica é tentar tornar esses vários fragmentos em um pensamento contínuo e claro, o que tem sido uma tarefa bastante profícua. Sobretudo por formulações que Goethe faz e que nos parecem a primeira vista conflitantes. Nesse sentido, a discussão sobre a possibilidade ilimitada do pesquisador da natureza de compreender os fenômenos e objetos naturais esbarra em determinadas colocações que trazem consigo a demarcação de limites do conhecimento. Goethe adjudica a Kant um "modo jocosamente irônico, ora parecendo esforçar-se sem limitar ao máximo a capacidade cognitiva, ora apontando para além dos limites que ele mesmo havia delineado" (Goethe, 2011, p.85). Limites que, conforme veremos a seguir, ele também apresenta, mas de forma bastante distinta.

Goethe ressalta em seu texto de 1817, "Influência da filosofia moderna", uma concordância com as ideias de Kant:

[...] tão logo se começou a discutir sobre essa questão, tomei partido do lado que confere mais honra ao homem, e dei minha plena aprovação a todos os amigos que, com Kant, afirmavam: mesmo que todo o nosso conhecimento ande de mãos dadas com a experiência, nem por isso todo ele nasce dessa mesma experiência. Eu estava de acordo também com os conhecimentos a priori, bem como com os juízos sintéticos a priori. (Goethe, 2011, p.80-1) 
Ele se aproveitava da doutrina kantiana, "assimilando muitas coisas para meu uso pessoal" (ibidem, p.81). A leitura da Critica do juizo lhe conferiu um sentimento de prazer e felicidade por ver aproximados "esses dois mundos infinitos [cujos produtos] deviam existir por si mesmo" (ibidem, p.82). Estabelecia-se então claramente uma relação recíproca, mas não causal entre o mundo da arte e o da natureza: "Alegrava-me o fato de que a arte poética e a ciência natural comparada fossem tão afins entre si, e que ambas as coisas estivessem subordinadas à mesma capacidade de julgar" (ibidem, p.82). Entretanto, as coincidências de seu pensamento com o que entendia da doutrina kantiana não encontravam eco nos intérpretes do filósofo de Königsberg de sua época: "Mais de uma vez aconteceu de alguns admitirem, com um sorriso de admiração, que o que eu dizia guardava realmente certa analogia com o modo de pensar de Kant, mas eu dizia coisas diferentes" (ibidem, p.83). K. Hata, ao analisar o parentesco que Goethe estabelece entre os princípios da arte e o da natureza, sintetiza de modo claro a distinção entre ambos como algo resultante de distintos pontos de vista:

Kant analisa a arte sob o ponto de vista do observador ou do espectador e determina a relação entre natureza e arte como algo derivativo. Goethe, ele mesmo um poeta, cria obras de arte e experimenta essa relação. A explicação de Goethe advém, por isso, de um princípio dinâmico do produtor, enquanto Kant se ocupa com a teoria enquanto um legislador filosófico. (Hata, 2017, p.43)

A importância do processo criador, portanto, será o grande destaque da ciência goetheana e seu interesse pelo estudo da natureza só se concretizará de forma sistemática e contínua após sua mudança para Weimar e depois de já ser aclamado como poeta. Segundo Dorothea Kuhn (HA v.13, p.562): "A ciência de Goethe possui um pressuposto poético". O exercício laboral de criar poeticamente como que lhe despertou um sentido para a observação da natureza, o que será fundamental para o assentamento de suas ideias. Esse exercício prático da criação o torna sensível para ressaltar na natureza a capacidade de renovação das formas e também para transpor essa ação criativa como pressuposto também para o investigador da natureza, que, para conhecê-la de forma imediata, deve criar em si os órgãos para tal, constituindo-se, segundo acepção de F. Amrine (1998), em uma "metamorfose do cientista". Segundo o germanista americano, Goethe se coloca em oposição a uma ciência da mensuração ou da quantificação de absolutamente tudo, até daquilo que não seria possível de ser quantificado, que se baseia em estreitos princípios matemáticos como uma tentativa de restringir o papel da subjetividade no processo de conhecimento. Para Goethe isso representaria um "empobrecimento do conhecimento" (Amrine, 1998, p.40), já para o "cientista convencional, matemática é o único fiador de certeza, enquanto percepção e pensar são as fontes de todos os erros" (ibidem).

Ao pinçar e se utilizar do conceito de intelectus archetypus para estabelecer um diálogo com a filosofia de seu tempo, Goethe acreditava estar se desven- 
cilhando da possibilidade de "adentrar no labirinto" (Goethe, 2011, p.81) da teoria kantiana e, em diálogo e sintonia com a "filosofia moderna", adjudicar o que assinalava como a contraparte necessária, conforme destacamos acima. Tal conceito lhe permitiu passar, no terceiro parágrafo do texto em questão, para a reunião de dois conceitos que lhe serão caros e fundamentais: a possibilidade de se formar imagens como meio de conhecimento de uma natureza em devir e unitária, residindo nisso o que caracterizou como "juízo intuitivo". Esse tipo de intelecto mencionado por Kant como possibilidade de suprir a carência de imagens do intelecto discursivo, Goethe toma não como possibilidade, mas como comprovação de sua existência, indo ao encontro do que procurava desenvolver com sua ideia de fenômeno originário. Se para Kant a aproximação do divino se daria pelo lado moral, em Goethe ela surge como desenvolvimento do juízo intuitivo que desvela a ideia de forma imagética: "No campo intelectual, poderia muito bem acontecer de, mediante a contemplação de uma natureza cada vez mais criadora, nós nos tornarmos dignos da participação espiritual em suas produções" (Goethe, 2011, p.84). Essa almejada "participação espiritual" que muito bem poderia indicar uma potência infinita do homem, surge de forma contrária nos seguintes versos do Fausto, conforme Mefistófeles caracteriza o homem:

De mundo, sóis, não tenho o que dizer,

Só vejo como se atormenta o humano ser.

Da terra é sempre igual o mísero deusito,

Qual no primeiro dia, insípido e esquisito.

Viveria ele algo melhor, se da celeste

Luz não tivesse o raio que lhe deste;

De Razão dá-lhe o nome, e a usa, afinal,

Pra ser feroz mais que todo o animal.

(Goethe, v.279-289, 2016, p.51)

Surgem assim duas opiniões acerca da capacidade criadora do homem. Enquanto no texto sobre a capacidade de formação de conceitos acerca da natureza alude-se a uma potência infinita da natureza da qual o homem poderia ser partícipe através do desenvolvimento do juízo intuitivo, a fala de Mefistófeles no Fausto reduz o homem a um "deusito desse mundo", expressando uma visão do homem que o torna menor, como um ser restrito ao uso instrumental de suas capacidades intelectivas-racionais, fazendo-o incapaz de promover qualquer atitude rumo a um desenvolvimento, ao desdobramento de uma formação (Bildung). A razão (Vernunft) que foi dada ao homem no ato de criação como um tipo de reflexo da própria luz celeste (Schein des Himmelsreichs) pode ser considerada um espelhamento do ato criador divino, mas seria usada, segundo Mefistófeles, apenas como instrumento de dominação, sobretudo da natureza. $\mathrm{O}$ que poderia ser grandiosamente divino e potente restringiu-se a um exercício mesquinho da capacidade humana. A ciência moderna, conforme se desenvol- 
veu paulatinamente a partir da Renascença, é assim caracterizada por Meyer-Abich (1987, p.351):

Toda ciência pressupõe decisões sobre o que se gostaria de conhecer; isto é, o que deve ser apreendido pela investigação científica. Na ciência moderna da natureza, por exemplo, vale a pena saber como os fenômenos podem ser produzidos e reproduzidos. O ideal do conbecimento - a concepção orientadora da verdade científica a ser buscada - é, portanto, desde o início, um estado de coisas que é compreendido quando podemos produzi-lo; em outras palavras, é a aquisição de poder na natureza. O juízo de valor sobre o que vale a pena conhecer precede, então, o trabalho científico, está em seu pano de fundo e aparece nos objetos da ciência apenas no tipo de interesse que assumimos $[\ldots]$.

Dessa forma, a ciência moderna, por questões de princípios, rejeita o ponto de vista e, por conseguinte, a metodologia propostos por Goethe. A sucinta descrição feita pelo físico alemão dos propósitos da ciência moderna, torna a razão instrumental nela empregada como algo similar ao descrito por Mefistófeles: o uso da razão é associado ao uso da violência, para que se promova a superação da natureza e, como consequência, tem-se uma ciência voltada para domínio e subjugação dela. A superação estabelecida por Goethe é aquela em que se abandona o uso de nosso senso comum, em busca do encontro da potência criadora no ato de conhecimento enquanto verdade que espelha a "luz celeste". Assim se expressa Mefistófeles em referência ao que Fausto acabara de renunciar ao realizar o pacto: "Vai-te e despreza o gênio (Vernunft) e a ciência, / Do ser humano a máxima potência" (Goethe, Fausto, v.1851-1852). Para que não se efetue no modo de conhecer a natureza um tal abandono, há de se almejar uma aliança entre razão e ciência que deve ser conseguida através da efetividade do juízo intuitivo. Tal fim, segundo Goethe, só pode ser alcançado pelo aperfeiçoamento da experiência, o que garantiria um desenvolvimento contínuo da capacidade de percepção, transmutado em um olhar da natureza enquanto devir, não como um objeto a ser dominado. Assim resume Amrine a distinção entre a metodologia de Newton e a de Goethe em referência ao estudo das cores:

Diante desse deslocamento, de produto por processo, pode-se entender a repetida insistência de Goethe de que seu trabalho científico precisava ser feito para ser entendido. Por exemplo, ele escreve da Itália que seu "sistema vegetal" é "difícil de escrever em qualquer caso e impossível de compreender a partir da mera leitura, mesmo que tudo tenha sido escrito de forma tão precisa e adequada" (Goethe HA XI, p.400). A noção sutil de múltiplas Vorstellungsarten [tipos de representação] de Goethe revela quão profundamente ele compreendeu que toda percepção é "carregada de teoria". Foi em parte por essa razão que Goethe se opôs veementemente ao experimentum crucis de Newton, argumentando que um único experimento não prova nada. Igualmente importante era sua noção fundamentalmente diferente de experimentação científica. Para Goethe, o 
experimento não é como um silogismo único e prático, mas sim como uma prática artística voltada para o refinamento da percepção de uma pessoa ao longo do tempo. Novamente, vemos que o objetivo primário da ciência, como Goethe entende, deve ser o autodesenvolvimento, a metamorfose do cientista. (Amrine, 1998, p.39)

Esse refinamento do cientista apontado por Amrine pode muito bem ser interpretado em conformidade com as mesmas leis que regem o processo criador da natureza e que efetivamente podem promover a metamorfose. Essas leis foram descritas no texto "Esclarecimento sobre o ensaio aforístico A natureza" (1828), escrito para explicar ao amigo Friedrich von Müller que havia perguntado a Goethe se o texto encontrado no espólio da Grã-duquesa Anna Amália seria de sua autoria. Apesar do fragmento em prosa, que mais tarde comumente passou-se a nomear de "A natureza", possuir um acentuado tom elegíaco e expressar o pensamento de Goethe por volta de 1780, ele foi escrito pelo teólogo Georg Christoph Tobler (1757-1812) a quem Goethe conhecera por ocasião de uma viagem à Suíça e que estampara naquele ensaio o conteúdo das conversas entabuladas. Nele se encontra o resumo das ideias de Goethe desenvolvidas ao longo dos dez anos de estada em Weimar, uma fase que finda com sua viagem à Itália por meio da formulação das leis sobre a metamorfose das plantas. No texto de Tobler-Goethe, a vitalidade da natureza é expressa de forma tal que arrebata e enreda o sujeito numa teia de eterna produtividade, mas sem que se atenha detidamente ao aspecto do fenomênico no desenvolvimento das formas, o que só seria realizado com os trabalhos posteriores de Goethe. Ainda como típico exemplo de expressão das impressões meramente subjetivas, esse texto atem-se à expressão do sentimento humano diante da potência criadora da natureza:

Natureza! Estamos cercados e envolvidos por ela - incapazes de sair dela e incapazes de penetrá-la mais profundamente. [...] Ela cria eternamente novas formas; o que vem a existir não existiu jamais, e o que existia não volta a existir - tudo é novo e, mesmo assim é sempre antigo. Nós vivemos em meio a ela e lhe somos estranhos. Ela fala conosco incessantemente e não nos confidencia seu segredo. (Goethe, 2011, p.107)

E assim segue adiante o texto de Tobler sem que as formas da natureza sejam merecedoras de qualquer destaque ou que se tornem ponto de partida para o processo investigativo. No texto destinado a esboçar a diferença com seu pensamento de então, distante em quase meio século daquele primeiro, o próprio Goethe aponta a existência outrora de "uma espécie de panteísmo, imaginando-se um inescrutável, incondicionado, humorístico e autocontraditório ser, subjacente aos fenômenos do mundo" (Goethe, 2011, p.111). Faltava naquela época a consciência da existência de princípios produtivos, vitais, conceituados por Goethe como polaridade (Polarität) e intensificação (Steigerung). Em texto de 1805 , intitulado "Polaridade", ele já havia apresentado sob o este nome "alguns elementos universais" ou "princípios fundamentais" com os quais se produz por sua interação opositiva "a maior diversidade possível”. ${ }^{32}$ 
Esses pares de opostos são ligados à própria materialidade dos fenômenos e objetos, seguindo o princípio de "atração e repulsão". O outro princípio é o "impulsionador da natureza" e de ordem espiritual que tem por objetivo o alcance de uma "ascensão". Os dois princípios reúnem em si matéria e espírito e são responsáveis pela criação das formas. Quase uma década antes, Goethe escrevera o texto "Impulso de formação" (Bildungstrieb), no qual sintetiza de forma esquemática sua concepção do que seria a vida. Compreendida entre matéria e forma, a vida apresenta como forças motrizes para a sua exteriorização fenomênica o seguinte: "capacidade; força, poder; empenho e impulso" (Goethe, HA v.13, p.35). Esses aspectos que conferem forma à matéria não poderiam ser entendido, ainda segundo Goethe, "sem o conceito de metamorfose" (ibidem). Mas tudo isso seria interdito ao pesquisador da natureza sem que lhe fosse despertada capacidade imaginativa através do juízo intuitivo, o que teria acontecido com o próprio Goethe nos jardins da cidade de Palermo na Itália quando tem a intuição do que concebeu como a planta primordial. A ideia lhe perseguia como se fora um "fantasma" [Gespenst]. Sua "velha obsessão" de encontrar a matriz de todas as plantas se concretiza idealmente, conforme relata em carta de maio de 1787 a Charlotte von Stein:

Diga a Herder que estou bem próximo do segredo da geração e da organização das plantas e é o mais simples que se poderia pensar. Sob este céu é possível fazer as mais belas observações. Diga-lhe que não tenho mais dúvidas, que descobri claramente onde se encontra a essência das coisas, diga-lhe que agora sou capaz de contemplar tudo o mais no Todo e que apenas alguns pontos precisam ainda de melhor definição. A planta primordial será a criação mais prodigiosa do universo, pela qual a própria natureza deverá invejar-me. Com esse modelo e com a chave de acesso a ele pode-se descobrir um número infinito de plantas, em uma série consequente. Isso quer dizer que, mesmo que não existam, sua existência seria certamente possível, não como sombra e aparência artística ou poética, mas sim dotadas de uma verdade e necessidade interna. (Goethe, 2017b, p.299)

Sem qualquer dúvida do que ali se deu, Goethe noticia que teve acesso à "essência das coisas". Em seu íntimo se revelou uma imaginação ideal, concebida como uma criação puramente metafísico-imagética. O homem se torna criador e supera assim a natureza por ter a consciência do momento de descoberta do mundo. Goethe estabelece em cada reino da natureza formas primordiais (Urformen): o granito, o tipo e a planta primordial, mas pouco a pouco abandona essa procura pela forma proteica e prefere se enveredar pelo jogo formativo, se dedicar ao processo de metamorfose e, por conseguinte, ao desenvolvimento da capacidade imaginativa ao observar as formas em constante processo de transformação e de intuir o absoluto nos fenômenos se autodesenvolvendo. O pensar de Goethe dedicado ao mundo, acaba por se tornar um processo de autoconhecimento, uma forma de resolver o enigma da esfinge da forma mais irônica possível, desviando o olhar de si para fazer com que penetre em si. "O 
ser humano só conhece a si mesmo na medida em que conhece o mundo, do qual só toma consciência em si próprio e só no qual toma consciência de si. Cada novo objeto, bem contemplado, descerra um novo órgão em si” (Goethe. "Importante incentivo por meio de uma única palavra engenhosa"; 1823. 2011, p.102).

\section{Considerações finais:}

\section{uma bem vinda renovação do olhar da natureza}

Como vimos, a forma de Goethe olhar e conceber a dinâmica da natureza não teve espaço ao longo do desenvolvimento da ciência hegemônica, baseada na quantificação e fragmentação dos objetos de estudo. As discussões em vida raramente encontraram eco como em Nees von Esenbeck e em Carl Gustav Carus, além de em Martius e em Alexander von Humboldt. Dentre os adeptos da ciência cartesiana e newtoniana, Goethe só recebeu descrédito e críticas. Sua descoberta do osso intermaxilar feita em 1784 ficou conhecida apenas por poucos e desconhecida por parte do grande público. Assim também seus trabalhos de osteologia, sobretudo a respeito da teoria do desenvolvimento do crânio a partir dos ossos das vértebras, que foi recusada em 1859 por Thomas Henry Huxley.

Os fundamentos de seus pensamentos foram timidamente publicados. Os 12 números dos cadernos dedicados à morfologia de 1824 tiveram uma pequena tiragem: 1.000 exemplares da primeira série e 500 da segunda, contribuindo para o quase desconhecimento dessas atividades de Goethe. Saliente-se que à época o florescimento das publicações científicas começa a se incrementar e Goethe é cada vez mais tido como um estranho no ninho ou apenas como um diletante. Embora vários professores da Universidade de Jena tenham trabalhado com ele, como Justus Christian Loder (estudos de anatomia), Karl Batsch e Franz Joseph Schelver (estudos de botânica) e nomes da ciência de então como Kaspar Maria Graf von Sternberg, Hans Christian Oested e Jöns Jacob Berzelius tenham em seus anos de velhice trazido o nome de Goethe no seio de algumas discussões científicas, seus princípios permanecerem como uma alternativa à ciência hegemônica. Seus escritos sobre morfologia encontraram alguma ressonância, sobretudo os estudos sobre as folhas e seu desenvolvimento, enquanto sua mais cara doutrina, a respeito das cores, foi recebida entusiasticamente apenas em seu círculo de amigos, sendo criticada veementemente na parte em que se opõe a Newton. De sua portentosa obra sobre as cores, apenas a parte sobre o "Efeito sensível-moral da cor" e a "Parte histórica" foram merecedoras de destaque em variados âmbitos do conhecimento, como a psicologia e a história da ciência. Também de considerável recepção foram seus experimentos acerca das cores fisiológicas que resultaram da observação da atividade do olho na geração de cores.

Quando se põe um pequeno pedaço de papel ou qualquer objeto de seda de cor viva sobre um quadro branco moderadamente iluminado, e se olha fixamente 
para a pequena superfície colorida, removida depois de certo tempo sem que os olhos se movam, o espectro de uma outra cor deverá ser visto sobre o plano branco. Mesmo que o papel colorido permaneça no lugar, ao se olhar para outra parte do plano branco os fenômenos cromáticos também poderão ser vistos, pois surgem de uma imagem que doravante pertence ao olho. (Goethe, 1993c, p.62, grifo meu)

Essa descrição de uma experiência da parte "Imagens coloridas" da Doutrina das coves se encerra com a afirmação do pertencimento de determinadas cores ao olho, que é concebido por Goethe não como um mero "captador" de sensações, mas sim como um agente na produção de fenômenos. O olho é capaz de produzir cores, embora fugazes, mas tão reais quanto aquelas do mundo exterior, que classifica como físicas e químicas. O que ressalta aqui é a capacidade de se produzir elementos, o que, a princípio, somente a natureza poderia fazer.

Essa relação entre o interior e o exterior é formulada por Goethe em franca alusão ao neoplatonismo e dele retira a ideia de correspondência e união entre as leis de elaboração do mundo, as leis divinas do grande pagão, e as leis que dormitam no interior do homem:

O olho deve sua existência à luz. De órgãos animais a ela indiferentes, a luz produz um órgão que se torna seu semelhante. Assim o olho se forma na luz e para a luz, a fim de que a luz interna venha ao encontro da luz externa.

Lembremos aqui a antiga escola jônica, que com toda a gravidade sempre repetiu que "O igual só é conhecido pelo igual". Recordemos também as palavras de um antigo místico [Plotino], que em rimas alemãs podem ser expressas assim:

Se o olho não tivesse sol,

Como veríamos a luz?

Sem a força de Deus vivendo em nós

Como o divino nos seduz?

(Goethe, 1993c, p. 44-45)

Após o império da racionalidade iluminista, Goethe insere em um texto que almeja ser considerado de rígido teor científico conhecimentos antigos que prescindem do intelecto discursivo, fomentando impulsos que poderiam propiciar a intuição, o imagético. Esse aspecto místico-religioso do pensamento goetheano repercutiu pontualmente no início do século XX na arte (W. Kandinsky, Paul Klee, Antonio Gaudi), na filosofia (Ludwig Wittgenstein) e na psicologia (Carl G. Jung). Diversos cientistas também tomaram seus pensamentos como auxílio no desenvolvimento de outras formas de conceber o mundo e de entendimento sobre ele, como, por exemplo, Werner Heisenberg, um dos pilares da física quântica, que assim se expressou sobre Goethe:

Nós podemos ainda hoje aprender com Goethe já que ao privilegiar um determinado órgão, o da análise racional, deixamos embotar todos os outros; de modo que se trata muito mais de tomar a realidade com todos os 
órgãos que nos foram dados e nos entregarmos a isso, de tal forma que essa realidade também espelhe o essencial, o "unitário, o bom e o verdadeiro”. (Heisenberg, apud Bican; Wenzel, 2012, p.260)

Ao final do século XX, também podemos vislumbrar uma possibilidade de continuidade do diálogo com Goethe, através, por exemplo, da área do design e da arquitetura pelo surgimento da biomimética, concepção pela qual o olhar para a natureza e a harmonia existente nela fornecem inspiração para a criação de objetos e formas que possam trazer para a vida humana a sabedoria harmoniosa nela contida. Assim resume Janine M. Benyus em seu livro de 1997 os princípios da nova disciplina, que se vale de duas palavras gregas para compor o nome: “BI - O - MI - MÉ - TI - CA [Do grego bios, vida, e mimesis, imitação]", estabelecendo seus três princípios basilares: "l. A natureza como modelo; 2. A natureza como medida; 3. A natureza como mentora" (Benyus, 2007, p.8 ). Baseando-se na imitação e inspiração da natureza buscam-se soluções para situações da ciência do presente: "A biomimética é uma nova forma de ver e valorizar a natureza. Ela inaugura uma era cujas bases assentam não naquilo que podemos extrair da natureza, mas no que podemos aprender com ela" (ibidem). E já existem estudos que procuram entrelaçar o pensamento goetheano com essa nova forma de se conceber objetos e espaços: "Acreditamos que o método de Goethe pode ser empregado junto com o processo de design tradicional e tem o potencial de mudar fundamentalmente os relacionamentos dos designers com a natureza e, finalmente, com sua visão de mundo" (Irwin; Baxter, 2008, p.137). A mudança do olhar para a natureza implica em uma nova forma de interação com o mundo e consigo mesmo.

Não se quis neste trabalho fazer uma apologia idealista ao pensamento goetheano acerca da natureza, nem traçar em detalhes os vários caminhos por ele percorridos. A intenção foi a de apresentar a possibilidade de se resgatar uma visão prazerosa da natureza, na qual o domínio seja suplantado pela empatia e que nos possibilite olhar para o vivente com mais vagar, procurando não a subtração de elementos cada vez mais essenciais para o estilo de vida que se escolheu levar, mas sim apresentando a alternativa, a possibilidade de novas escolhas, não tão práticas, mas que resgatam o humano em cada um de nós. Se é de utopia que se faz o futuro, Goethe estará inscrito nele.

\section{Notas}

1 Foram utilizadas como referência às edições da obras completas de Goethe as seguintes abreviaturas: HA Hamburger Ausgabe / MA Münchener Ausgabe /WA Weimarer Ausgabe.

2 Goethe. Epigramas venezianos, HA v.1, p.181.

3 Essa lacuna tem sido paulatinamente suprida neste século no Brasil com a publicação de ensaios acerca da atividade cientifica de Goethe, assim como pela tradução e publicação 
de coletâneas de seus textos sobre o tema, assim como pela pesquisa em universidades refletidas em esparsas monografias e teses.

4 Com o grão-duque, se empenhou por dotar a Universidade de Jena com os mais modernos instrumentos de ótica e física da época, o que teve como consequência direta o desenvolvimento industrial da cidade como um dos maiores centros de ótica da Alemanha.

5 Base da hodierna Biblioteca Anna Amália, uma das mais famosas bibliotecas do mundo.

6 Johann Kaspar Lavater (Zurique, 1741-1801), pastor, filósofo, poeta, teólogo suíço, considerado como o fundador da fisiognomia, estudo dos semblantes das pessoas para o delineamento de características da personalidade. Seu livro Physiognomische Fragmente zur Beförderung der Menschenkenntnis und Menschenliebe (1775-1778) contou com a colaboração de Goethe.

7 Friedrich Heinrich Jacobi (Düsseldorf 1743 - Munique 1819), embora hoje raramente mencionado, foi uma das personalidades filosóficas mais populares na Alemanha da época, autor de vários livros com críticas a Kant e a Schelling.

8 Disponível em: <http://www.zeno.org/Literatur/M/Goethe,+Johann+Wolfgang/ Briefe/1812>.

$9 \mathrm{Na}$ série sobre a morfologia, Goethe reuniu seus antigos textos sobre botânica, anatomia e zoologia em conjunto com outros de caráter mais autobiográfico. Nos últimos cadernos dessa série, encontramos além de pequenos tratados, exposição de observações e aforismos de Goethe, textos de amigos colaboradores. Na segunda série, Goethe reuniu textos sobre óptica, estudos sobre as nuvens, sobre previsões do tempo e de geologia.

10 Goethes nachgelassene Werke. Hrsg. v. Eckermann und Riemer. 20 Bde. (Band 41-60 der Ausgabe letzter Hand). Stuttgart, Tübingen: Cotta 1832-1842. Os volumes 50 a 60 reúnem os textos de ciência da natureza.

11 As duas edições são: Große Cotta-Ausgabe: Sämmtliche Werke in 40 Bänden. Vollständige, neugeordnete Ausgabe. Stuttgart, Tübingen: J. G. Cotta, 1840. Dazu: Reg.-Bd. 1842; Hempelsche Ausgabe: Werke. Nach den vorzüglichsten Quellen revidirte Ausgabe. 36 Tle. in 23 Bdn. Berlin: G. Hempel o. J. (1868-79). [Mitarbeiter: W. v. Biedermann, H. Düntzer, u. a. Erste kommentierte Goethe-Ausg.]

12 Goethes Werke. Vollständige Ausgabe letzter Hand, Bd. 1-40. Stuttgart; Tübingen: Cotta, 1827-1830.

13 A primeira seção foi composta por 55 obras literárias distribuídos em 63 volumes (1887-1918) com 27.409 páginas; a segunda seção com 16 volumes (1890-1904) reuniu 15 escritos de ciência natural em com 16.120 páginas; a terceira, reunindo os diários somaram 16 volumes (1887-1919) com 6.120 páginas e a quarta seção com a compilação da correspondência de Goethe compôs 50 volumes (1887-1912).

14 Weimarer oder Sophienausgabe: Goethes Werke. Hrsg. im Auftrage der Großherzogin Sophie von Sachsen. Abtlg. I-IV. 133 Bde. in 143 Tln. Weimar: H. Böhlau, 18871919. Repr. [Tb.-Ausg.] München: Deutscher Taschenbuch Verlag 1987. A edição é dividida em cinco partes: I. Obras (55v); II. Escritos natural-científicos (13v); III. Diários (15v); IV. Cartas (50v).

15 Todas essas edições foram digitalizadas e podem ser acessadas em: https://de.wikisource. org/wiki/Johann_Wolfgang_von_Goethe. 
16 Esenbeck era uma ferrenho admirador das ideias de Goethe acerca da metamorfose da plantas e passa a enviar para Weimar os exemplares da publicação Nova Acta Physico-Medica Academiae Caesareae Leopoldino-Carolinae Naturae Curiosorum. Goethe, por sua vez em retribuição, envia os exemplares do jornal que começara a publicar em 1817, Zur Naturwissenschaft überhaupt, besonders zur Morphologie.

17 Goethea é uma designação geral para vários tipos de plantas da família das malváceas que florescem no tronco e são típicas da mata atlântica.

18 Como parte das comemorações do centenário da morte de Goethe, foi plantada em 1932, por iniciativa de Roquette Pinto, uma muda no jardim do Petit Trianon da Academia Brasileira de Letras. Em 2001, foi promulgada a Lei Municipal ${ }^{\circ}$ 1887, de 24/10/2001, que cria a Reserva Biológica da Goethe no bairro de Itaipu (Niterói, RJ): “A criação da mencionada Reserva objetivou a proteção global da flora e fauna locais, com extensão de dez hectares, em honra ao notável Cientista e Literato Johann Wolfgang Goethe, Cidadão da Humanidade, no ano do centenário de seu falecimento" (Disponível em: <https://leismunicipais.com.br/a/rj/n/niteroi/ lei-ordinaria/2001/189/1887/lei-ordinaria-n-1887-2001-autoriza-o-poder-executivo-a-criar-o-espaco-memorial-da-reserva-biologica-goethea-em-itaipu-em-resgate-historico-da-primeira-e-mais-antiga-unidade-de-conservacao-ambiental-municipal-instituida-no-brasil>).

19 A primeira descrição da planta, Goethea, novum platarum genus, foi publicada na Nova Acta Leopoldina em 1823.

20 Goethe. Die Schriften zur Naturwissenschaft. Vollständige mit Erläuterungen versehene Ausgabe im Auftrage der Deutschen Akademie der Naturforscher Leopoldina begründet von K. Lothar Wolf und Wilhelm Troll. Herausgegeben von Dorothea Kuhn und Wolf von Engelhardt. Weimar: Hermann Böhlaus Nachfolger, 1947 ff. A edição é composta de três partes: LA I (11 volumes; textos de Goethe); LA II (10v; complementos e comentários); LA III (2v; índice geral, de citações e referências).

21 Além dos textos de cunho natural-científico, também fazem parte da edição comentários de personalidades da época, assim como poesias, trechos de obras, sobretudo de Fausto, Wilhelm Meister e Afinidades eletivas, partes de obras de cunho autobiográfico, cartas e diários de Goethe que possuem relação com seus interesses e estudos científicos. Os textos foram editados por área de estudo e ordenados cronologicamente.

22 Conforme aponta Nutt-Kofoth (2005, p.100): "De um ponto de vista histórico-científico, a Edição de Weimar é tida como uma obra do positivismo".

23 Disponível em: <http://www.hin-online.de/index.php/hin/article/viewFile/220/ 409/65>. Acesso em: 12 fev. 2019.

24 Assim se refere Heinrich Heine a Goethe em seu livro Quadros de viagem (Reisebilder): Heinrich Heine. Historisch-kritische Gesamtausgabe der Werke (DHA). Hamburg: Hoffmann und Campe, Band VI, 1973, p.146.

25 Ilustração de Johannes van Someren para o livro de Gerard Blaes (Blasius), Anatome animalium, terrestrium variorum, volatilium, aquatilium, serpentum, infectorum, ovorumque, structuram naturalem (Amsterdam, 1681). Disponível em: <https:// www.milestone-books.de/pages/books/001776/gerard-blaes-blasius/anatome-animalium-terrestrium-variorum-volatilium-aquatilium-serpentum-infectorum-ovorumque>. Acesso em: 12 fev. 2019. 
26 A influência de Espinosa em Goethe é assunto já atestado pela crítica, sobretudo pela fórmula lapidar hen kai pan (tudo e todo), característica não só em Espinosa, como em Giordano Bruno, ambos alvo de intensas leituras por parte de Goethe. O interesse de Goethe por Espinosa se inscreve no interesse geral que as ideias do filósofo despertaram na Alemanha de final do século XVIII pela publicação do livro de F. H. Jacobi, Sobre a doutrina de Espinosa em cartas ao senhor Moses Mendelssohn (1785), que desencadeou a chamada "disputa panteísta" (Pantheismusstreit).

27 J. W. von Goethe, “Testamento” (Goethe, 1986, p.233-5).

28 Publicado na segunda série dos cadernos "Sobre ciência da natureza em geral II", I, 1823 e escrito na mesma época que as "Contribuições para a óptica", texto preliminar do que mais tarde veio a ser a "Doutrina das cores". O ensaio seria um prefácio ao texto, mas acabou não sendo utilizado por Goethe com esse propósito.

29 Essa caracterização encontra-se em carta de Goethe de 28 de agosto 1796 ao anatomista Samuel Thomas Soemmerring: “[...] por que não deveríamos nós, empiristas e realistas, conhecer também aqueles que nos cercam e entender nossa vantagem? (Goethe, WA-IV, Bd. 11, S. 177).

30 Manuscrito editado postumamente na Edição de Weimar com este título e em outras edições com "Fenômeno puro" e como anexo a uma carta a Schiller de 17 jan. 1798, na qual Goethe submete o texto à apreciação do amigo de ideias: "Quero lhe escrever a seguir um resumo geral, a fim de que possa apresentar meu método, o objetivo e sentido do trabalho" (Goethe, HA v.13, p.567).

31 Ver nota em HA v.13, p.568.

32 Desse modo formam-se os pares "nós e os objetos; luz e escuridão; corpo e alma; duas almas; espírito e matéria; Deus e o mundo; pensamento e expansão; ideal e real; sensibilidade e razão; fantasia e intelecto; ser e anseio; duas metades do corpo; direita e esquerda; respirar; experiência física: ímã" (Goethe, "Polaridade". 2011, p.77-78).

\section{Referências}

AMRINE, F. The Metamorphosis of the Scientist. In: AMRINE, F.; SEAMON, D.; ZAJONC, A. Goethe's way of science: a phenomenology of nature. New York: State University of New York Press, 1998. p.33-54.

. The Unconscious of Nature. Analyzing Disenchantment in Faust I. In: Goethe Yearbook. San Francisco: The Goethe Society of North America, 2010. v.17, p.117-32.

BENYUS, Janine M. Biomimética: inovação inspirada pela natureza. São Paulo: Editora Pensamento-Cultrix, 1997.

BICAN, B.; WENZEL, M. Rezeptions- und Wirkungsgeschichte. In: WENZEL, M. (Ed.) Goethe Handbuch. Supplemente Band 2; Naturwissenschaften. Stuttgart; Weimar: Verlag J.B. Metzler, 2012. p.251-89.

BORCHMEYER, D. Sophiens Reise von Weimar nach München. Zum Nachdruck der Weimarer Ausgabe. In: Goethe-Jabrbuch, 1989, p.230-9.

BRUHNS, K. (Ed.) Alexander von Humboldt. Eine wissenschaftliche Biographie. Bd. 1. Leipzig: F. A. Brockhaus, 1872. 
ECKERMANN, J. P. Conversações com Goethe nos últimos anos de sua vida: 1823-1832. Trad. Mário L. Frungillo. São Paulo: Editora Unesp, 2016.

ECKLE, J. Die Leopoldina-Ausgabe. „Goethe. Die Schriften zur Naturwissenschaft”. In: Weimar - Jena: Die große Stadt, Verlag Vopelius, 5/4, p.299-307, 2012.

GOETHE, J. W. v. Goethes Werke. Vollständige Ausgabe letzter Hand, Bd. 1-40. Stuttgart; Tübingen: Cotta, 1827-1830.

. Goethes Werke. 14 Bände. Hamburg: Deutscher Taschenbuch Verlag, 2000.

[Hamburger ausgabe]

. Memórias: poesia e verdade. Primeiro volume. Trad. Leonel Vallandro. Brasília: Editora da Universidade de Brasília. Hucitec, 1986.

. Poemas - Antologia. Versão Portuguesa, Notas e Comentários: Paulo Quintela; 4.ed. Coimbra: Centelha, 1986. p.233-235.

Goethes Werke. Hrsg. im Auftrage der Großherzogin Sophie von Sachsen. Abtlg. I-IV. 133 Bde. in 143 Tln. Weimar: H. Böhlau, 1887-1919. Repr. [Tb.-Ausg.] München: Deutscher Taschenbuch Verlag 1987. [Weimarer Ausgabe]

. A metamorfose das plantas. Trad., introd., notas e apêndices de Maria Filomena Molder. Lisboa: Imprensa Nacional/Casa da Moeda, 1993a.

Acontecimento feliz. In: . A metamorfose das plantas. Trad., introd., notas e apêndices de Maria Filomena Molder. Lisboa: Imprensa Nacional, 1993b. p.72-4.

. Doutrina das cores. Trad. Marco Giannotti. São Paulo: Nova Alexandria, 1993c. tras, 1999.

. Viagem à Itália (1786-1788). Trad. Sérgio Tellaroli. São Paulo: Cia. das Le-

O experimento como mediador entre objeto e sujeito. In: Contribuições para a óptica. (1a. Parte). São Paulo: Antroposófica, 2011. p.117-33.

Ensaios científicos: uma metodologia para o estudo da natureza (Coletânea). Apres. e introd. Antonio José Marques. Sel. e trad. Jacira Cardoso. São Paulo: Barany Editora; Ad Verbum Editorial, 2012.

Teoría de la naturaleza. Estudio preliminar, traducción y notas de Diego Sánchez Madrid: Meca Editorial Tecnos, 2013.

Fausto - Uma tragédia (Primeira parte). 6.ed. rev. e ampl. Trad. Jenny Klabin Segall. São Paulo: Editora 34, 2016.

. Fausto - Uma tragédia (Segunda parte). 5.ed. rev. e ampl. Trad. Jenny Klabin Segall. São Paulo: Editora 34, 2017a.

Viagem à Itália. Trad. Wilma P. D. Maas. São Paulo: Editora Unesp, 2017 b.

GRAVE, J. Beweglich und bildsam. Morphologie als implizite Bildtheorie? In: MAATSCH, J. (Ed.) Morphologie Und Moderne: Goethes >Anschauliches Denken $<$ in den Geistes- Und Kulturwissenschaften Seit 1800. De Gruyter, 2014. p.57-74.

HADOT, P. O Véu de Ísis: ensaio sobre a história da ideia de natureza. São Paulo: Loyola, 2006.

HATA, K. Phantasie als Methode der poietischen Wissenschaft Goethes. Naturwissenschaft und Philosophie im Spiegel seiner Zeit. Wiesbaden: Springer VS, 2017. 
HEINE, H. Contribuição à história da religião e filosofia na Alemanha. Tradução de Márcio Suzuki. São Paulo: Iluminuras, 1991.

HEINRICH, A. Goethes Wissenschaft von der herrlich leuchtenden Natur. In: Goethe-Jabrbuch, 1989, p.106-18.

IRWIN, T.; BAXTER, S. The dynamical view of natural form. In: BREBBIA, C. A. Design und Nature IV. Comparing Design in Nature with Science and Engineering. Southampton, Boston: WIT Press, 2008. p.129-38.

JEßING, B.; LUTZ, B.; WILD, I. (Ed.) Metzler Goethe Lexikon. Personen, Sachen, Begriffe. Stuttgart; Weimar: J. B. Metzlar Verlag, 2004.

KUHN, D. Allgemeine Naturwissenschaft - Morphologie - Geologie. In: Hamburger-Ausgabe, HA: Goethes Werke. Hamburg, 1955, p.556-63.

MAATSCH, J. (Ed.) Morphologie und Moderne: Goethes “Anschauliches Denken" in den Geistes- und Kulturwissenschaften seit 1800. De Gruyter, 2014.

MAZZARI, M. V. Natureza ou Deus: afinidades panteístas entre Goethe e o "brasileiro" Martius. Estudos Avançados, São Paulo, v.24, n.69, p.183-202, 2010. Disponível em: <http://www.scielo.br/scielo.php?script=sci_arttext\&pid=S0103$-40142010000200012 \& \operatorname{lng}=$ pt\&nrm=iso $>$. Acessos em: 11 fev. 2019.

MEYER-ABICH, K. M. Self-Knowledge, Freedom, and Irony: The Language of Nature in Goethe. In: AMRINE, F.; SEAMON, D.; ZAJONC, A. Goethe's way of science: a phenomenology of nature. New York: State University of New York Press, 1998. p.351-71.

MOLDER, M. F. Introdução. In: GOETHE. J. W. v. A metamorfose das plantas. Trad. Maria Filomena Molder. Lisboa: Imprensa Nacional, 1993. p.9-29.

MOURA, M. dos S. A poiesis orgânica de Goethe: a construção de um diálogo entre arte e ciência. São Paulo, 2006. Tese (Doutorado) - Faculdade de Filosofia, Letras e Ciências Humanas, Universidade de São Paulo. São Paulo, 2006. Disponível em: <http://www. teses.usp.br/teses/disponiveis/8/8144/tde-09082007-141708/pt-br.php>.

NUTT-KOFOTH, R. Goethe Editionen. In: PLACHTA, B. Editionen zu deutschsprachigen Autoren als Spiegel der Editionsgeschichte. Tübingen: Max Niemayer Verlag, 2005. p.95-116.

SCHÖNE, A. Goethes Farbentheologie. München: Verlag C. H. Beck, 1987.

SEAMON, D.; ZAJONC, A. Goethe's way of science: a phenomenology of nature. New York: State University of New York Press, 1998.

WACHSMUTH, A. Nachwort. In: GOETHE, J. W. v. Schriften zur Botanik und Wissenschatslehre. München: Deutscher Taschenbuch Verlag, 1963. p.226-38.

WEIZSÄCKER, C. F. Einige Begriffe aus Goethes Naturwissenschaft. In: GOETHE, J. W. Goethes Werke. Band 13. Hamburg: Deutscher Taschenbuch Verlag, 2000. p.539555.

WENZEL, M. (Ed.) Goethe Handbuch. Supplemente Band 2. Naturwissenschaften. Stuttgart; Weimar: Verlag J.B. Metzler, 2012.

WYDER, M.; MUSCHG, A. Bis an die Sterne weit: Goethe und die Naturwissenschaften. Berlin: Insel Verlag, 1999. 
RESUMO - O nome de Goethe é comumente associado à sua vasta produção literária, sobretudo a Fausto e Wilhelm Meister. Os conceitos de romance de formação e de literatura mundial também estão intrinsicamente relacionados a seu ideário estético. Entretanto, o que escapa à maioria dos leitores de sua obra é que esses conceitos também surgem conexos a uma ação voltada para o conhecimento do mundo. A intenção deste trabalho é expor alguns preceitos conceituais que nortearam Goethe em sua ação de desvelamento dos segredos do mundo, contribuindo para uma extensão do conceito de formação para além do mundo das letras e vê-lo como parte imprescindível da prática científica goetheana.

PALAVRAS-CHAVE: Goethe, Morfologia, Natureza, Ciência, Formação.

ABSTRACT - Goethe's name is commonly associated with his vast literary production, particularly Faust and Wilhelm Meister. The notions of Bildungsroman and world literature are also intrinsically related to their aesthetic ideals. However, what escapes most readers of his work is that these concepts also arise in relation to efforts to know the world. The intention of this article is to expound some conceptual precepts that guided Goethe in his action of unveiling the secrets of the world, contributing to expand the concept of formation beyond the world of letters and to see it as an indispensable part of Goethean scientific practice.

KErWORDS: Goethe, Morphology, Nature, Science, Bildung.

Magali Moura é professora associada de Língua e Literatura Alemã na Universidade do Estado do Rio de Janeiro (UERJ), pesquisadora da obra de Goethe, com vários artigos científicos dedicados à sua obra. @-magali.moura@uol.com.br /

https://orcid.org/0000-0001-8568-5165

I Universidade do Estado do Rio de Janeiro, Rio de Janeiro, Brasil.

Recebido em 9.4.2019 e aceito em 16.5.2019. 
